UDC 338.48

http://doi.org/10.21272/mmi.2019.2-27

JEL Classification: L83, Z32, Z38, C82

\author{
Ludmila Melnyk, \\ D. Sc., Associate Professor, Uman National University of Horticulture, Ukraine \\ Inna Novak, \\ D. Sc., Associate Professor, Uman National University of Horticulture, Ukraine \\ Maryna Gomeniuk, \\ Ph.D., Associate Professor, Uman National University of Horticulture, Ukraine \\ Olha Pidlubna, \\ Uman National University of Horticulture, Ukraine \\ Olha Bezpalova, \\ D. Sc., Professor, Kharkiv National University of Internal Affairs, Ukraine
}

\title{
THE DETERMINANTS OF TOURISM DEVELOPMENT: THE EXAMPLE OF POTENTIAL CANDIDATES FOR THE EU MEMBERSHIP
}

\begin{abstract}
The paper deals with the analysis of the main indicators which influence on tourism development. The authors analysed and systematized the main determinants of tourism development for potential candidates for the EU membership. Thus, the object of investigation was Ukraine, Moldova and Georgia during 2000-2017. The authors theoretical justified the relationship between the country's economic development and efficiency of the tourism industry. For analysis, the Partial Least Squares Path Modelling (PLS-PM) using latent variables was used. In addition, the proposed model, along with traditional economic and social indicators, considering the innovative, environmental and political components. The basis of this model was the structural equations which described the interdependence of both latent variables (internal part of the model) and their descriptive indicators (the external part of the model). The empirical results confirmed the statistically significant relationship between the economic, social, innovative, environmental and political components at the level of 0.8-0.9 by the coefficient alpha Cronbach. The proposed model of PLS-PM allowed highlighting the main directions of tourism development for Ukraine, Moldova and Georgia. In addition, the proposed model allocated the gap between the real situation in the analysed countries and the social and economic development of the EU countries. The findings indicated that the development of the tourism industry depends on the ecological and social indicators of the countries' development. In addition, for Ukraine, excluding the environmental and social indicators, the country's image is influenced by political stability. At the same time, the dynamic political reforms in Georgia led to an increase in the country's popularity among tourists. The authors highlighted, that the assessment of the relationship between tourism and social, economic, environmental and innovative development could be the basis for the development strategy of the tourism considering the macroeconomic stability of the country.
\end{abstract}

Keywords: tourism, model, factors, EU, tourist, economic development, stability.

Introduction. Ongoing world tendency of vulnerable economic development provokes the stringing of the world competitiveness among all sectors and spheres. Besides, the world leader countries try to attract additional financial recourses into economic from different sources. Thus, one of the most perspective ways to attract additional capital into the national economy is developing of tourism in the country. The well-developed tourism industry attracts new stakeholders into the country through formatting the national touristic brand. In this case, each country tries to focus on the promotion of tourism on the own peculiarities and features: nature; museums; art; dancing and etc. It should be underlined, that development of tourism as an alternative way to attract foreign investment allows to strengthen the country's economic indicators.

Tourism is the significant sector in EU through its economic potential and employment options. Thus, in EU despite of an average fluctuations level of GDP per capita (25,67\%) Table 1, the volume of tourist is normal around the trend line $(18,76 \%)$. The most stable dynamic of analysed indicators (which characterised by the slight variation $-0-10 \%$ ) have the countries as follows: Belgium $(8,24 \%)$, France

Cite as: Melnyk, L., Novak, I., Gomeniuk, M., Pidlubna, O., \& Bezpalova, O. (2019). The Determinants of Tourism Development: the Example of Potential Candidates for the EU Membership. Marketing and Management of Innovations, 2, 326-336. http://doi.org/10.21272/mmi.2019.2-27 
L. Melnyk, I. Novak, M. Gomeniuk, O. Pidlubna, O. Bezpalova. The Determinants of Tourism Development: the Example of Potential Candidates for the EU Membership

(4,8\%), Luxembourg $(9,06 \%)$, in the average 11-25\% - Austria (15,59\%), Cyprus $(14,28 \%)$, Czech Republic $(22,38 \%)$, Germany $(24,8 \%)$, Spain $(15,92 \%)$, Finland $(14,59 \%)$, United Kingdom $(16,11 \%)$, Greece $(24,77 \%)$, Hungary $(21,98 \%)$, Ireland $(15,24 \%)$, Italy $(12,72 \%)$, Lithuania $(22,08 \%)$, Malta $(23,47 \%)$, Netherlands $(21,52 \%)$, Poland $(11,86 \%)$, Romania $(24,04 \%)$, Slovak Republic $(17,75 \%)$, Sweden (17,46\%), 25-50\% - Bulgaria (29,93\%), Denmark (35,84\%), Estonia (31,15\%), Latvia (32,27\%), Portugal $(37,89 \%)$, Slovenia $(33,55 \%)$. It allowed EU to attract additional financing - 4,98264E+11 US\$. The huge rate of tourism income to GDP was in Croatia, Spain, France, Cyprus, Malta, Italy, Great Britain. Such results justified the economic importance of tourism in the analysed countries' development.

Table 1. The fluctuation's characteristics of GDP per capita (current US\$), International tourism, number of arrivals, International tourism, receipts (current US\$) for EU, 1995-2017 years

\begin{tabular}{|c|c|c|c|c|c|}
\hline Variable & $\mathrm{CV}$ & Mean & Std. Dev. & Min & Max \\
\hline gdp & 25.67 & 28303.75 & 7267.986 & 18250.31 & 38198.6 \\
\hline $\begin{array}{l}\text { International tourism } \\
\text { number of arrivals } \\
\text { receipts }\end{array}$ & $\begin{array}{l}18.74 \\
29.09\end{array}$ & $\begin{array}{l}3.66 e+08 \\
3.54 e+11\end{array}$ & $\begin{array}{l}6.86 e+07 \\
1.03 e+11\end{array}$ & $\begin{array}{l}2.59 e+08 \\
2.16 e+11\end{array}$ & $\begin{array}{l}5.23 e+08 \\
4.98 e+11\end{array}$ \\
\hline
\end{tabular}

Source: authors' calculations based on the World Bank data, estimated with Stata 14.0.

The findings for 1995-2017 years for EU proved the statistically significant correlations between GDP per capita, International tourism, number of arrivals, International tourism, receipts. This linking could be shown as a regression equation (figure 1).
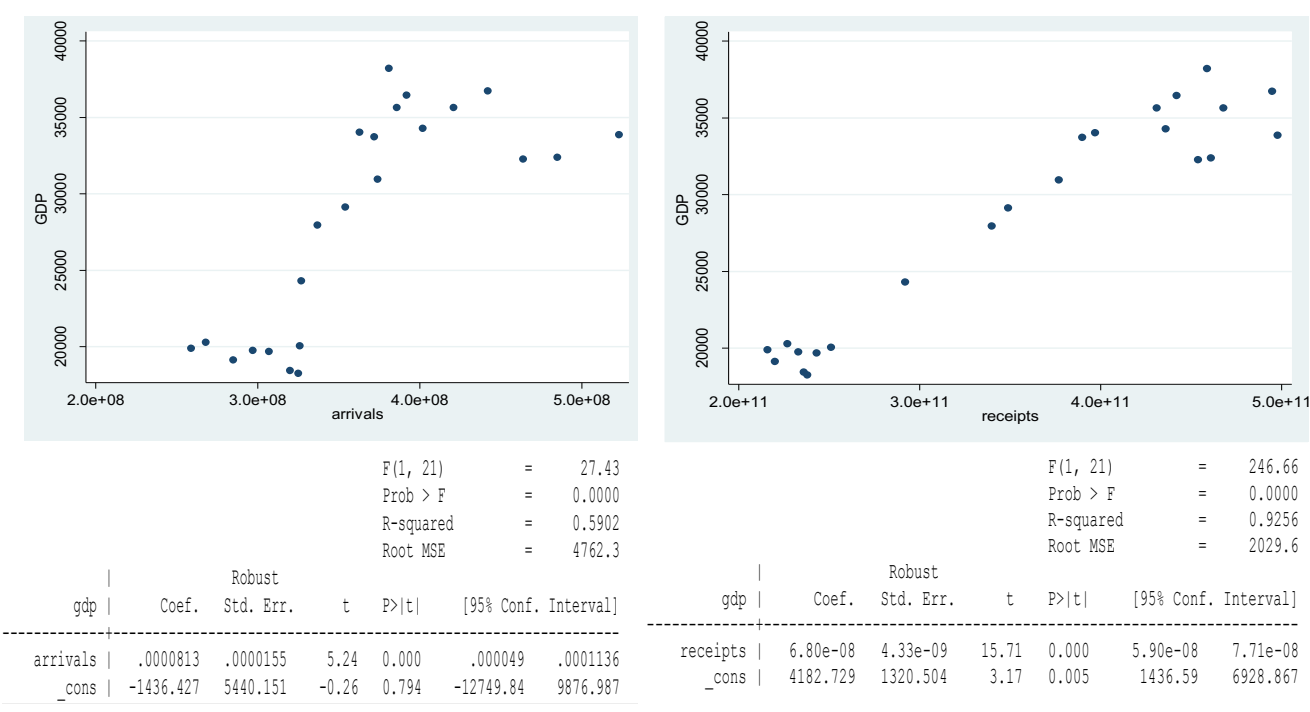

Figure 1. The linking between GDP per capita (current US\$), International tourism, number of arrivals, International tourism, receipts (current US\$) for EU, 1995-2017 years

Source: authors' calculations based on the World Bank data, estimated with Stata 14.0. 

Potential Candidates for the EU Membership

The findings of Figure 1 allowed making a conclusion that tourism's developing in the EU is a driver for social and economic development.

Literature Review. In scientific publications, tourism was analysed as the key role in stimulating social and economic countries' development. As a consequence, it leads to the macroeconomic stability of the national economy through developed additional value which influences on increasing GDP; increasing foreign currency from touristic services; new workplace and increasing peoples' welfare in the touristic region; increasing profit of companies which provide the touristic services; supporting entrepreneurship and innovation. Thus, in the paper (Lyulyov et al, 2018) analysed the brand impact on macroeconomic stability. They tried to estimate the economic efficiency from countries' brand using considering the tourism benefits. It allowed checking hypothesis on linking between brand awareness and macroeconomic indicators of the brand used by the country. In the paper (Brida \& Risso, 2009) the authors checked the hypothesis on cause-effect relationships between tourism expenditure, real exchange rate and economic growth. The authors highlighted that for 1986-2007 years the economic growth in Chili relates from extending of international tourism. Thus, increasing of touristic cost by $100 \%$ lead to increasing of real GDP by $80 \%$. That investigation based on the estimating of cointegration ratio between variables which should be increased in the nearest future using Vector Error Correction (VEC) model (1):

$$
\Delta Y_{t}=\mu+\Pi Y_{t-1}+\sum_{i=1}^{\mathrm{i}=k-1} \Gamma_{\mathrm{i}} \Delta Y_{t-\mathrm{i}}+\varepsilon_{t},
$$

where $Y$ - real GDP, real exchange rate, tourism expenditure - vector containing the variables, $\mu$ is a vector of constant terms.

The cointegration relation between tourism and economic growth was analysed in the papers as follows: J. Balaguer and M. Cantavella-Jordà (2002) on the Spanish example; J.G. Brida, B. Lanzilotta, W.A. Risso (2008) - Uruguay; N. Dritsakis (2004) - Greece; L. Wang, H. Zhang, W. Li (2012) - China. The findings of the analysed papers proved that economic growth in the long-term period relates to the efficiency of economic policy on tourism regulation. Thus, increasing of domestic tourist arrivals in China's by $1 \%$ lead to increasing of GDP by $0,8 \%$ (Wang et al., 2012), in Spain increasing of touristic activities by $5 \%$ in the long-term time leads to increasing of domestic real income by $1.5 \%$ (Dritsakis, 2004). Fayissa, Nsiah and Tadasse (2007) used the modified Cobb-Douglass model (2) based on panel data of 42 African countries during 1995-2004 years proved that «10 per cent increase in the spending of international tourists leads to. 0.4 per cent increase in the GDP per capita income». The authors agreed with the results of scientists as follows: O. Edgar (1987) and A. N. Sen (1999), that the necessary requirements of touristic impact on the country's economic growth are achieving social, ecological and political conditions:

$$
\begin{aligned}
& \ln P C I_{i t}=\beta_{0}+\beta_{1} \ln T R P_{i t}+\beta_{2} \ln G C F_{i t}+\beta_{3} \ln E F I_{i t}+\beta_{4} \ln S C H_{i t}+\beta_{5} \operatorname{lnFDI}_{i t}+ \\
& \beta_{6}{\ln T O T_{i t}}_{i t} \beta_{7} \ln H H C_{i t}+\varepsilon_{i t}
\end{aligned}
$$

where PCl - real GDP per capita, TRP - tourist receipts per capita in US\$, GCF - investment in physical capital, EFI - economic freedom index, $\mathrm{SCH}$ - secondary and tertiary school enrolment, FDI foreign direct investment, TOT - the openness of the economy, HHC - household consumption expenditures.

J.A. Mazanec, K. Wöber, A.H. Zins (2007) based on the findings of World Travel and Tourism Council and N. Gooroochurn, G. Sugiyarto (2005) did the theoretical justification of the additional considering the economic, social, cultural, technological and ecological factors for developing of the competitive touristic industry with purpose to increase the national economic growth in the long-term time (Figure 2). 
L. Melnyk, I. Novak, M. Gomeniuk, O. Pidlubna, O. Bezpalova. The Determinants of Tourism Development: the Example of Potential Candidates for the EU Membership

P.U. Dieke (2003) on the example of African countries did conclusion that for developing countries tourism is the additional financial resources, incentive instruments to decrease the social inequality through the developing new workplaces. In this case, the tourism industry for developing countries should be the key part of their economic strategy.

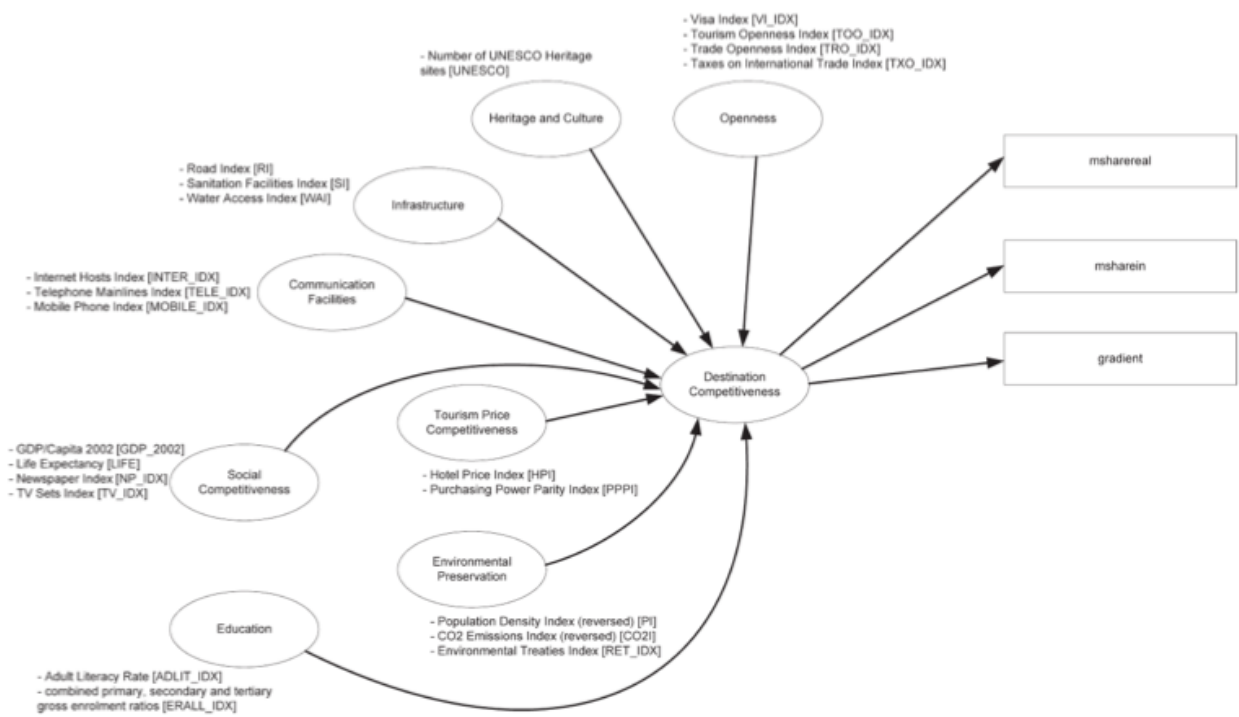

Figure 2. An explanatory model of destination competitiveness

Sources: Mazanec et al, 2007

At the same time, the results of the investigation of the scientist C. Webster and S. Ivanov (2014) focused on the analysis of tourism impact on the economic growth of 131 countries for 2000-2010 years showed that linking between analysed factors were not statistically significant for some regions. The authors highlighted, that such findings are the results of the quality of economic policy and government efficiency on tourism development in those regions. In the basis of that investigation was the economic and mathematical model with variable $g_{r}^{t}$ (tourism's contribution to economic growth):

$g_{r}^{t}=b_{0}+b_{1} \cdot T T C I+b_{1} \cdot P P L+b_{2} \cdot \ln P P L+b_{3} \cdot \ln G D P+b_{4} \cdot \ln T$ ourGDP $+b_{5} \cdot \ln$ GDPcapita + $b_{6} \cdot$ TourShare $+b_{7} \cdot E U+b_{8} \cdot A F+b_{9} \cdot A S+b_{10} \cdot L A+b_{11} \cdot N A+b_{12} \cdot O C+b_{13} \cdot L D C+b_{14}$. $O E C D$,

where TTCI - travel and tourism competitiveness (travel and tourism competitiveness index 2011), PPL - population size (log average population (2000-2010) - both sexes combined, as of 1st July of the respective year), GDP - economy size (log average GDP (1999e2009) in USD in 2011 prices), TourGDP - tourism GDP (log average Travel and tourism GDP (2000-2010) in USD in 2011 prices), GDPcapita economic wealth of local population (log average per capita GDP (1999-2009) in USD in 2011 prices), TourShare - tourism share in country GDP (Average share of tourism GDP (1999-2009)), EU, AF, AS, LA, NA, OC - geographic region (dummy variables for geographic regions), LDC - least developed country (dummy variable), OECD - OECD member state (dummy variable). 

Potential Candidates for the EU Membership

Besides, the results of papers L.L. Chen and J. Devereux, (1999) proved the negative impact of tourism on economic growth for countries oriented on export taxes or import subsidies. Considering above mentioned, the main goal of the paper is an analysis of the impact of economic, social, ecological, political and technological country's indicators on stable tourism development.

Methodology and research methods. The investigation based on using the Partial Least Squares Path Modelling (PLS-PM) (Wold, 1973) with using the latent variables which were proposed in the papers (Mazanec et al, 2007; Pablo-Romero et al, 2016) and proposed indicators which characterized the country's innovation development and governance efficiency (Table 2).

Table 2. The latent variable of the model and explanation indicators

\begin{tabular}{|c|l|}
\hline Latent Variables $\left(\mathbf{L}_{\mathbf{i}}\right)$ & \multicolumn{1}{|c|}{ Indicator $\left(\mathbf{G}_{\mathbf{i}}\right)$} \\
\hline \multirow{3}{*}{ Environmental development } & $\begin{array}{l}\text { Population density } \\
\text { CO2 emissions } \\
\text { renewable energy }\end{array}$ \\
\hline \multirow{3}{*}{ Social development } & $\begin{array}{l}\text { Human development index } \\
\text { Global hunger index } \\
\text { GNI per capita (current US\$) }\end{array}$ \\
\hline \multirow{5}{*}{ Government development development } & $\begin{array}{l}\text { Global innovation index } \\
\text { Research and development expenditure (\% of GDP) } \\
\\
\text { Networked readiness index }\end{array}$ \\
& $\begin{array}{l}\text { Voice and Accountability } \\
\text { Political Stability and Absence of Violence/Terrorism } \\
\text { Government Effectiveness } \\
\text { Regulatory Quality } \\
\text { Control of Corruption } \\
\text { Rule of Law }\end{array}$ \\
\hline Tourism & $\begin{array}{l}\text { People with basic handwashing facilities including soap and water (\% } \\
\text { of the population) } \\
\text { International tourism, receipts (current US\$) }\end{array}$ \\
\hline
\end{tabular}

Sources: developed by the author on the basis (HDR, 2019; GHI, 2019; GII, 2017; NRI, 2017; World Bank, 2019)

A. Diamantopoulos and H. M. Winklhofer in the paper «Index construction with formative indicators: An alternative to scale development» (Diamantopoulos and Winklhofer, 2001) based on the investigation (Bollen \& Lennox.,1991) which analysed the linking between latent variables and the main indicators (Figure 3) proposed to explain in using the multiple indicators and multiple causes (MIMIC) model. This model based on the structural equitation which explained the linking between latent variables (internal part of the model) and indicators (external part model). 


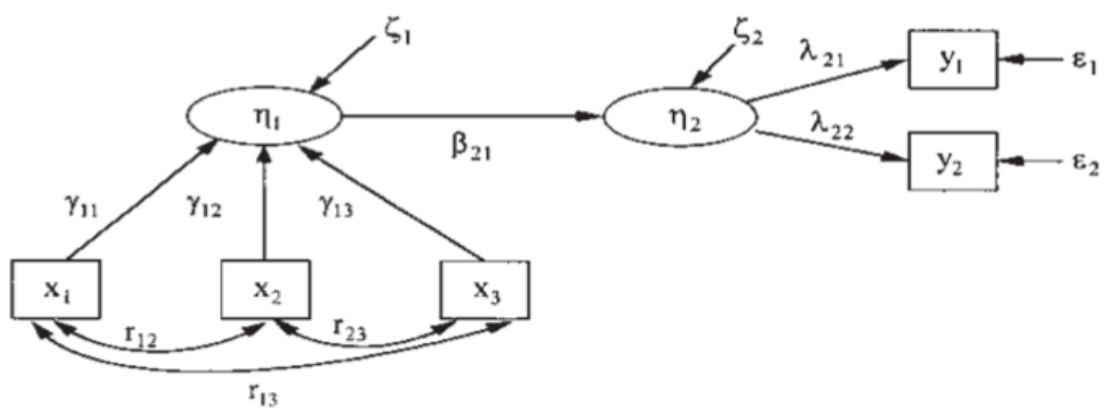

Figure 3. The model with formative and reflective indicators

Sources: Diamantopoulos and Winklhofer, 2001.

In this research, the internal and external parts of the model of linking the latent variables (Table 2) showed in Figure 4 and explained by the structural equitation (4) and (5).

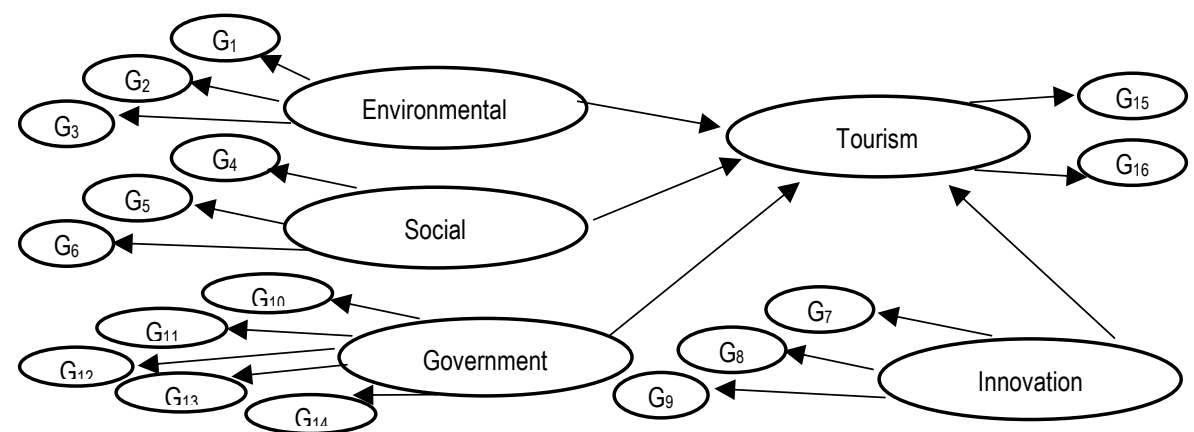

Figure 4. MIMIC model of analysis of the latent variables linking

Sources: developed by the authors

The external model:

LTourism $=\alpha_{0}+\alpha_{1} L$ Environmental $+\alpha_{2} L$ Social $+\alpha_{3} L$ Innovation + $\alpha_{4} L$ Government $+\varepsilon_{j}$

where LTourism, LEnvironmental, LSocial, LInnovation, LGovernment - the latent variables; $\alpha_{0 \ldots 4}$ - coefficients of power and directions connection; $\varepsilon_{j}$-standard errors.

The internal model:

$$
\left\{\begin{array}{l}
L \text { Tourism }=\sum \omega_{i, \text { Tourism }} G_{i, \text { Tourism }} \\
L \text { Environmental }=\sum \omega_{i, \text { Environmental }} G_{i, \text { Environmental }} \\
L \text { Social }=\sum \omega_{i, \text { Social }} G_{i, \text { Social }} \\
L \text { Innovation }=\sum \omega_{i, \text { Innovation }} G_{i, \text { Innovation }} \\
L \text { Government }=\sum \omega_{i, \text { Government }} G_{i, \text { Government }}
\end{array}\right.
$$

where $\omega_{i, \text { Tourism }} \ldots \omega_{i, \text { Government }}-$ weight coefficients. 
L. Melnyk, I. Novak, M. Gomeniuk, O. Pidlubna, O. Bezpalova. The Determinants of Tourism Development: an Example of Potential Candidates for the EU Membership

Results. The findings from the comparative analysis of GDP, the volume of tourist and foreign direct investment among potential candidates for EU membership showed that the tendency of all indicators is the same for 2004-2017 years. In this case, the following hypothesis, that GDP, volume of tourist and foreign direct investment are relating. Thus, the increase in tourists' volume could lead to increasing GDP and foreign direct investment. The findings in Table 3 showed that the highest volume of tourists for all analysed countries was 2007 and 2008 years before the world financial crisis had started. Noted, that for Ukraine in 2013 all indicators started rapidly decreasing which explained by the political and military conflicts. In Moldova and Georgia after 2013, the volume of tourist started increasing which as the consequences of implemented reforms which were the requirement of EU integrations.

Table 3. The dynamic of GDP, the volume of tourist and foreign direct investment

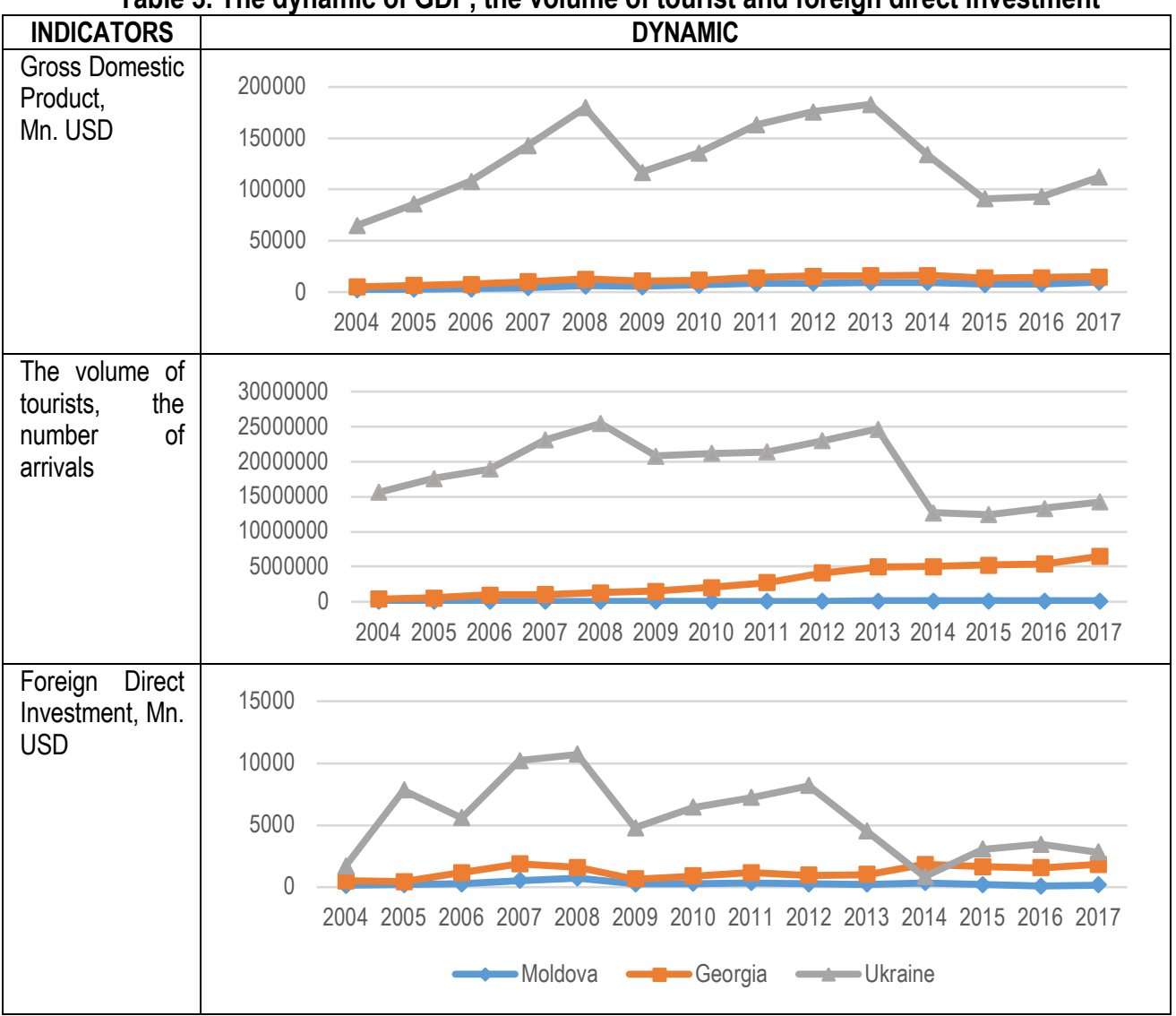

Sources: developed by the authors on the basis (World, 2019).

The results of the analysis of scientific background on the tourism industry showed that on its efficiency influenced the huge range of factors such as political stability; safety in the country; country's technological level; environmental safety and etc. The Cronbach's alpha was calculated at the first step of using the PLS-PM method. Thus, the findings showed a significant impact at the level 0,8-0,9 between environmental, social, innovation and government development for all analysed countries. Table 3 showed 
L. Melnyk, I. Novak, M. Gomeniuk, O. Pidlubna, O. Bezpalova. The Determinants of Tourism Development: the Example of Potential Candidates for the EU Membership

the findings of the internal model of the latent variables for Ukraine, Moldova and Georgia. Table 4 contains the results of the external model of linking between latent variables.

Table 3. The calculation results of the internal model of the latent variable for Ukraine, Moldova and Georgia

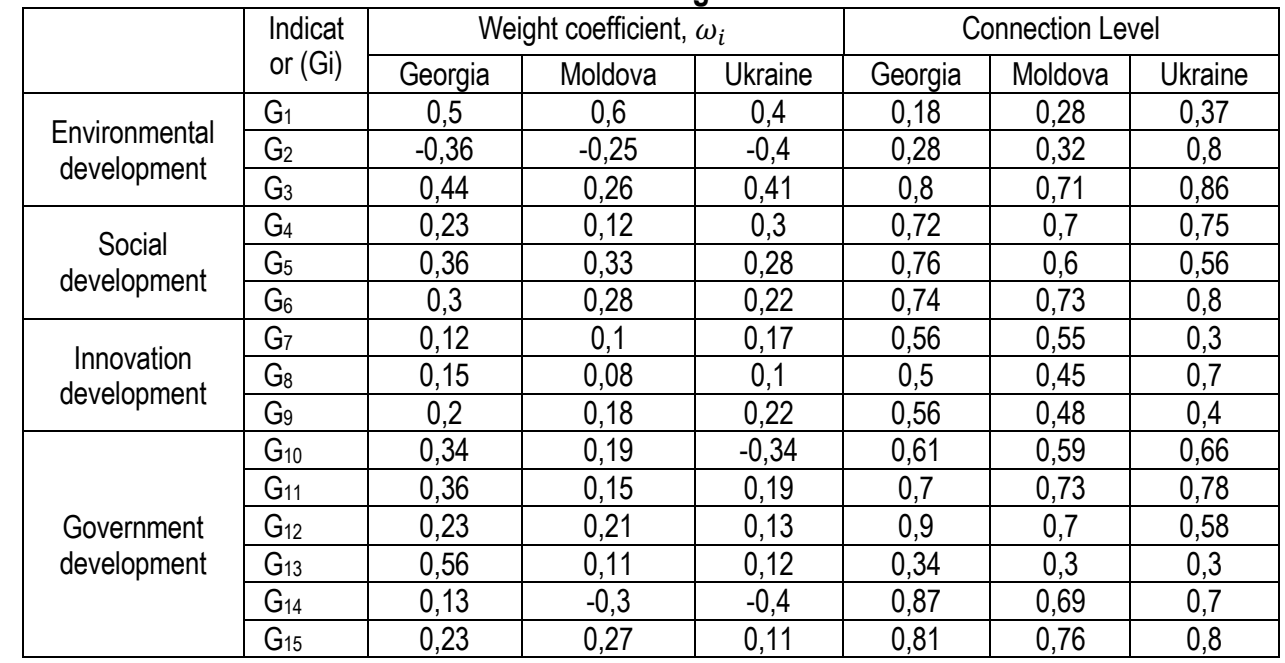

Sources: developed by the authors.

Table 4. The calculation results of the external model of the latent variable for Ukraine, Moldova and Georgia

\begin{tabular}{|c|l|l|l|}
\hline \multicolumn{1}{|c|}{ Coef. } & \multicolumn{1}{c|}{$\mathrm{t}-$} & $\mathrm{P}>|\mathrm{t}|$ \\
\hline \multicolumn{4}{|c|}{ Georgia } \\
\hline Environmental development & 0.282 & 9.88 & 0.000 \\
\hline Social development & 0.2463 & 10.55 & 0.000 \\
\hline Innovation development & 0.963 & 1.537 & 0.125 \\
\hline Government development & 0.302 & 4.084 & 0.000 \\
\hline \multicolumn{4}{|c|}{ Moldova } \\
\hline Environmental development & 0.3901 & 14.718 & 0.000 \\
\hline Social development & 0.121 & 1.900 & 0.061 \\
\hline Innovation development & 0.032 & 1.228 & 0.220 \\
\hline Government development & -0.1883 & -0.97 & 0.367 \\
\hline \multicolumn{4}{|l|}{ Ukraine } \\
\hline Environmental development & 0.237 & 3.582 & 0.000 \\
\hline Social development & 0.1055 & 0.09 & 0.931 \\
\hline Innovation development & 0.0033 & 0.70 & 0.487 \\
\hline Government development & -0.721 & -19.65 & 0.000 \\
\hline
\end{tabular}

Sources: developed by the authors

Thus, according to the results in Table 4, the most statistically significant impact had the factors which explained the environmental and the social development for all analysed countries. Besides, the government development indicators were statistically significant for Georgia and Ukraine. At the same time, for Ukraine this relation was negative. It should be underlined, that innovation development had a weak impact on tourism development for analysed countries. The obtained results allowed making a 
conclusion for possible directions for each analysed country to develop the tourism industry. Thus, Ukraine should pay attention to Government efficiency and Innovation development. It means, that Ukraine should develop the incentive and regulatory instruments to synchronise the abovementioned policy with the strategy of tourism development. In this case, Georgia should improve the environmental policy which improves the corresponding indicators. In addition, this policy should consider the EU norms and standards in that sphere. Besides, all countries as the protentional candidates to EU membership should adopt their policies according to the EU policy of tourism development.

Conclusion. The obtained results of EU countries experience on tourism development showed a positive correlation between the level of tourism development and the country's economic growth. Thus, the findings proved that increasing tourists lead to the growth of GDP and foreign direct investment. Besides, EU countries try to promote tourism's brand of the country through implementing the common development policy and open boundaries.

The proposed PLS-PM model allowed to allocate a bullet point for the potential candidate to EU membership on developing the tourism industry. Besides, using this model showed the gap between the real situation and social-economic development of EU countries.

Thus, the findings proved that tourism development relates to the factors as follows: environmental and social indicators. Besides, for Ukraine excluding environmental and social indicators the political stability and corruption level influence on the tourist's image of the country. In particular, the dynamic politic reforms lead to increasing the country's popularity among tourists.

From the other side, understanding of the relationship between tourism and social, economic, environmental and innovation development allowed to create the strategy of tourism development with the purpose to improve the macroeconomic stability of the country.

Author Contributions: conceptualization, methodology, software, validation, investigation, resources, data curation - L.M., L.N., M.G., O.P, O.B.

\section{References}

Balaguer, J. and Cantavella-Jordà, M. (2002) Tourism as a long-run economic growth factor: the Spanish case, Applied Economics, vol 34, pp. 877-884.

Bilan, Y., Gavurova, B., Stanisław, G., \& Tkacova, A. (2017). The Composite Coincident Indicator (CCI) for Business Cycles. Acta Polytechnica Hungarica, 14(7), 71-90.

Bilan, Y., Streimikiene, D., Vasylieva, T., Lyulyov, O., Pimonenko, T., \& Pavlyk, A. (2019). Linking between Renewable Energy, CO2 Emissions, and Economic Growth: Challenges for Candidates and Potential Candidates for the EU Membership. Sustainability, 11(6), 1528.

Bollen, K., \& Lennox, R. (1991). Conventional wisdom on measurement: A structural equation perspective. Psychological bulletin, 110(2), 305.

Brida, J. G., \& Risso, W. A. (2009). Tourism as a factor of long-run economic growth: an empirical analysis for Chile. European Journal of Tourism Research, 2(2), 178-185

Brida, J.G., Lanzilotta, B., Risso, W.A. (2008) Turismo y crecimiento económico: el caso de Uruguay, PASOS: Revista de Turismo y Patrimonio Cultural, Vol. 6, No. 3, pp. 481-492, 2008

Brożyna, J., Mentel, G., \& Szetela, B. (2017). Renevable energy and economic development in the European Union. Acta Polytechnica Hungarica, 14(7), 11-34

Chen, L. L., \& Devereux, J. (1999). Tourism and welfare in Sub-Saharan Africa: a theoretical analysis. Journal of African Economies, 8(2), 209-227.

Diamantopoulos, A., \& Winklhofer, H. M. (2001). Index construction with formative indicators: An alternative to scale development. Journal of marketing research, 38(2), 269-277.

Dieke, P. U. (2003). Tourism in Africa's economic development: policy implications. Management decision, 41(3) 287-295.

Dritsakis, N. (2004) Tourism as a long-run economic growth factor: an empirical investigation for Greece using 
causality analysis, Tourism Economics, vol. 10(3), pp.305-316.

Edgar, O. (1987). The future of freedom in the developing world.

Fayissa, B., Nsiah, C., \& Tadasse, B. (2008). Impact of tourism on economic growth and development in Africa. Tourism Economics, 14(4), 807-818.

GHI, (2019). Global hunger index. The International Food Policy Research Institute (IFPRI). Retrieved from: http://www.ifpri.org/publication/concept-global-hunger-index-1

GII, (2019). Global innovation index. Cornell University, INSEAD, and the World Intellectual Property Organization Retrieved from : https://www.globalinnovationindex.org/analysis-indicator

Gooroochurn, N., \& Sugiyarto, G. (2005). Competitiveness indicators in the travel and tourism industry. Tourism Economics, 11(1), 25-43.

HDR, (2019). Human Development Report. United Nations Development Program.. Retrieved from : http://hdr.undp.org/en/content/human-development-index-hdi

Ibragimov, Z., Lyeonov, S., \& Pimonenko, T. (2019a). Green investing for SDGS: EU experience for developing countries. Economic and Social Development: Book of Proceedings, 867-876.

Ibragimov, Z., Vasylieva, T., \& Lyulyov, O. (2019b). The national economy competitiveness: effect of macroeconomic stability, renewable energy on economic growth. Economic and Social Development: Book of Proceedings, 877-886.

Lyulyov, O., Chygryn, O., and Pimonenko, T. (2018). National Brand as a Marketing Determinant of Macroeconomic Stability. Marketing and Management of Innovations, 3, 142-152. http://doi.org/10.21272/mmi.2018.3-12

Mazanec, J. A., Wöber, K., \& Zins, A. H. (2007). Tourism destination competitiveness: from definition to explanation?. Journal of Travel Research, 46(1), 86-95.

Pablo-Romero, M. D. P., Gómez-Calero, P., \& Sánchez-Rivas, J. (2016). Tourism, Competitiveness and Economic Growth: A New Analytical Model. Tourism-from Empirical Research towards Practical Application, 111.

Sen, A.N., 1999, Development as Freedom, New York: Alfred A. Knopf.

Wang, L., Zhang, H., \& Li, W. (2012). Analysis of Causality between Tourism and Economic Growth Based on Computational Econometrics. JCP, 7(9), 2152-2159.

Webster, C., \& Ivanov, S. (2014). Transforming competitiveness into economic benefits: Does tourism stimulate economic growth in more competitive destinations?. Tourism Management, 40, 137-140.

Wold, H. (1973). Nonlinear iterative partial least squares (NIPALS) modelling: some current developments. In Multivariate Analysis-III (pp. 383-407). Academic Press.

World Development Indicators.

https://databank.worldbank.org/reports.aspx?source=2\&series=BX.KLT.DINV.CD.WD\&country=\#

Л. Мельник, д.е.н., доцент, Уманський національний університет садівництва, (Україна);

I. Новак, д.е.н., доцент, Уманський національний університет садівництва, (Україна);

М. Гоменюк, к.е.н., доцент, Уманський національний університет садівництва, (Україна);

О. Підлубна, Уманський національний університет садівництва (Україна);

О. Безпалова, д.ю.н., профресор, Харківський національний університет внутрішніх справ (Україна).

Детермінанти розвитку туристичної галузі: приклад країн-кандидатів вступу до ЄС

Статтю присвячено аналізу основних факторів впливу на розвиток туристичної галузі. Авторами проаналізовано та систематизовано основні детермінанти розвитку туризму в країнах-кандидатах до вступу ЄС. Так, об'єктом дослідження обрано Україну, Молдову та Грузію у період 2000-2017 роки. У статті теоретично обгрунтовано залежність економічного розвитку держави від ефективності функціонування туристичної галузі. Для аналізу використано Partial Least Squares Path Modeling (PLS-PM) з використанням латентних змінних. При цьому запропонована модель поряд із традиційними економічними та соціальними індикаторами враховує інноваційну, екологічну та політичну складові. В основі даної моделі покладено використання структурних рівнянь, які описують взаємозалежність як латентних змінних (внутрішня частина моделі), так і їх описових індикаторів (зовнішня частина моделі). Емпіричні результати дослідження підтверджують статистично значущий зв'язок на рівні 0,8-0,9 за коефіцієнтом альфа Кронбаха 
L. Melnyk, I. Novak, M. Gomeniuk, O. Pidlubna, O. Bezpalova. The Determinants of Tourism Development: an Example of Potential Candidates for the EU Membership

між економічними, соціальними інноваційними, екологічними та політичними складовими. Запропонована модель PLS-PM дозволила виділити основні напрями розвитку туризму для України, Молдови та Грузії. Крім того, використання запропонованої моделі дало підстави виокремити розриви між реальною ситуацією в аналізованих країнах та соціально-економічним розвитком країн €С. Отримані результати свідчать, що ефективність ффункціонування туристичної галузі залежить від екологічних та соціальних показників розвитку країн. Крім того, для України, окрім екологічних та соціальних індикаторів на туристичний імідж країни впливає політична стабільність. При цьому динамічні політичні реформи в Грузії призвели до збільшення популярності країни серед туристів. Авторами доведено, що результати оцінки взаємозв'язку між туризмом та соціальним, економічним, екологічним та інноваційним розвитком може стати підгрунтям для формування стратегії розвитку туристичної галузі з метою покращення макроекономічноі стабільності країни.

Ключові слова: туризм, модель, фактори, ЄС, турист, економічний розвиток, стабільність.

Manuscript received:

(C) The author(s) 2019. This article is published with open access at Sumy State University. 